J. Med. Microbiol. - Vol. 25 (1988), 289-293

(C) 1988 The Pathological Society of Great Britain and Ireland

\title{
Identification of gram-positive anaerobic cocci by use of systems for detecting pre-formed enzymes
}

\author{
D. A. MURDOCH, I. J. MITCHELMORE and S. TABAQCHALI
}

Department of Medical Microbiology, St Bartholomew's Hospital, London EC1A 7BE

\begin{abstract}
Summary. Two systems for detecting pre-formed enzymes, RapID ANA and a prototype system from API, were compared in a blind study for their ability to identify 69 gram-positive anaerobic cocci isolated from clinical specimens. Both systems were able to identify Peptostreptococcus anaerobius, Ps. asaccharolyticus and $P s$. micros accurately without the need for further tests. The prototype API system identified all isolates of Ps. magnus correctly, but the RapID ANA system misidentified several isolates as Ps. micros. Numerous different enzyme patterns were found with the indole-negative, butyrate-producing cocci ( $P$ s. prevotii and Ps. tetradius), suggesting that this group of organisms may be heterogeneous. We conclude that kits for detecting preformed enzymes are of considerable potential for the identification of gram-positive anaerobic cocci in clinical laboratories.
\end{abstract}

\section{Introduction}

Gram-positive anaerobic cocci (GPAC) are major components of the commensal flora of man (Finegold, 1977) and important causes of human disease (Wren et al., 1977; Bourgault et al., 1980; Gorbach, 1985). Their taxonomy was previously based on gas-liquid chromatography (GLC) of fatty-acid metabolic products and carbohydrateutilisation tests (Holdeman et al., 1977), but most GPAC have very little or no saccharolytic activity (Ezaki and Yabuuchi, 1985). Recent attempts to provide a more satisfactory classification have been based on the homology groups and guanine-pluscytosine content of the DNA (Ezaki et al., 1983; Huss et al., 1984), GLC analysis of cell fatty acids and metabolic products (Lambert et al., 1979), and analysis of cell-wall structure (Weiss, 1981). However, they have provided conflicting data and it is not surprising that little effort is made to identify isolates of GPAC in most clinical laboratories.

Most GPAC use the breakdown products of proteolysis as their major energy source (Rogosa, 1974; Ezaki and Yabuuchi, 1985). Several commercial systems that detect pre-formed bacterial enzymes, including a range of proteolytic enzymes, have been marketed recently, so their ability to identify GPAC in a clinical laboratory was investigated. Several clinical isolates were characterised according to the scheme of Sutter et al. (1986); they were then examined blindly with two pre-formed

Received 15 June 1987; accepted 12 Aug. 1987 enzyme systems-RapID ANA and a new prototype system from API.

\section{Materials and methods}

\section{Bacterial strains}

A set of 95 isolates of gram-positive anaerobic cocci was originally tested; 82 were clinical isolates from St Bartholomew's Hospital, and 13 were strains from patients undergoing urological surgery at the London Hospital, Whitechapel. None of the organisms grew in an aerobic atmosphere containing $\mathrm{CO}_{2} 5-10 \%$ after incubation for one week.

\section{Initial identification}

For isolates, gram-stained smears were examined and indole production was tested with Indole Spot disks (Lab M, Bury) after incubation for $48 \mathrm{~h}$ on non-selective agar (Brucella Medium Base, Difco, with horse blood 6\%). Production of volatile and non-volatile fatty acids was determined by GLC (Holdeman et al., 1977), after incubation for $48 \mathrm{~h}$ in Robertson's Cooked Meat broth (Southern Group Laboratories, Hither Green, London). Antibiotic sensitivity testing was performed by the antibiotic disk method, with metronidazole 5- $\mu \mathrm{g}$ and vancomycin 5 $\mu$ g disks (Mast Laboratories, Merseyside) and sodium polyanethol sulphonate (SPS) 1-mg disks (Oxoid). Organisms that were resistant to metronidazole or vancomycin were not examined further.

Of the original 95 strains, 82 could be identified by the scheme of Sutter et al. (1986); 69 of these were tested for their pre-formed enzyme patterns ( 58 general clinical strains and 11 urological strains). 
Table I. Biochemical reactions of RapID ANA system

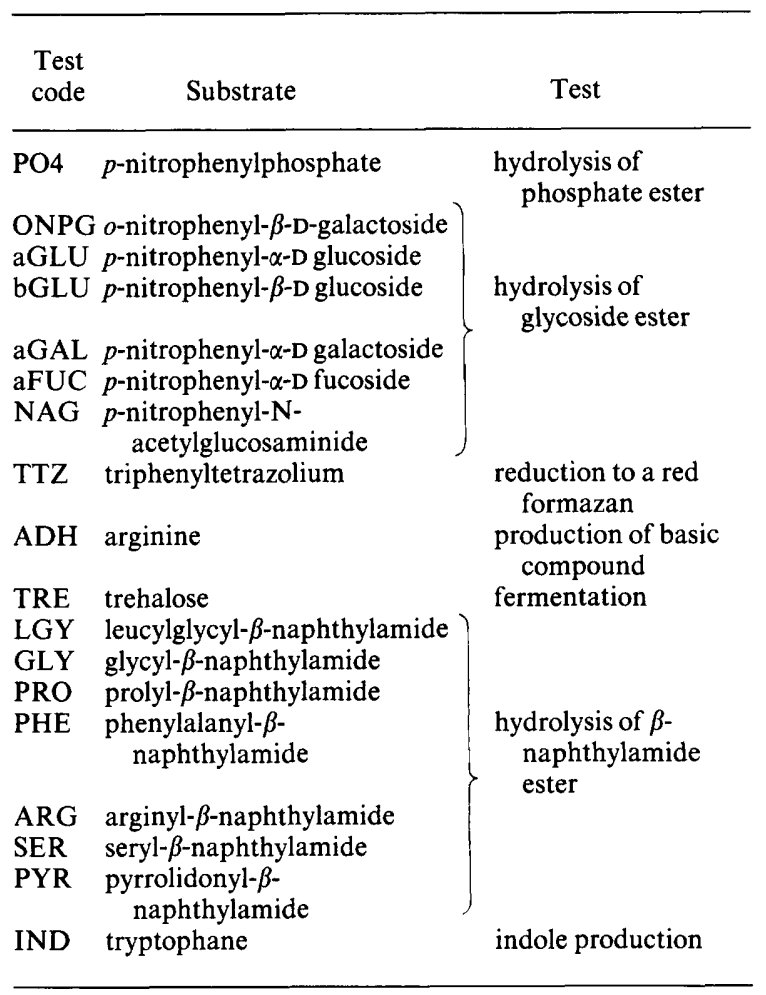

\section{Inoculation of pre-formed enzyme kits}

All strains were coded and plated out to check for viability and purity. A single colony was sub-cultured on to freshly prepared Columbia blood agar (Oxoid) with horse blood $6 \%$ and Vitamin $\mathrm{K} 10.1 \%$, and the plates were incubated for $48 \mathrm{~h}$. A separate observer who did not know the identity of the organisms inoculated the kits according to the instructions of the manufacturer with a bacterial suspension of density McFarland standard 4 (bacterial count $c .10^{9} \mathrm{cfu} / \mathrm{ml}$ ). Kits were then incubated aerobically at $37^{\circ} \mathrm{C}$ for $4 \mathrm{~h}$.

\section{The RapID ANA system}

The RapID ANA system (Mercia Diagnostics, Guildford, Surrey) is based on 18 biochemical reactions (table I) (Karachewski et al., 1985). Eight of the cupules are bifunctional; reactions were read before and after the addition of reagents, and were described as either positive or negative depending on the colour change. Tests were assigned numerical values, and the resulting six digit code was interpreted with the RapID ANA Code Compendium for identification.

\section{The prototype API system}

This new system (from API Laboratory Products, Basingstoke, Hants) consists of 32 biochemical reactions
Table II. Biochemical reactions of API prototype system

\begin{tabular}{|c|c|c|}
\hline Test no. & Test code & Test \\
\hline $\begin{array}{l}1 \\
2\end{array}$ & $\begin{array}{l}\text { ADH } \\
\text { GDC }\end{array}$ & $\begin{array}{l}\text { Arginine dihydrolase } \\
\text { Glutamate decarboxylase }\end{array}$ \\
\hline $\begin{array}{l}3 \\
4 \\
5 \\
6 \\
7 \\
8 \\
9 \\
10 \\
11\end{array}$ & $\begin{array}{l}\text { aGAL } \\
\text { bGAL } \\
\text { aGLU } \\
\text { aFUC } \\
\text { aARA } \\
\text { bGAL-6PH } \\
\text { N-Ac-GLU-NH2 } \\
\text { bGLU } \\
\text { bGUR }\end{array}$ & $\begin{array}{l}\text { Hydrolysis of glycoside } \\
\text { ester }\end{array}$ \\
\hline $\begin{array}{l}12 \\
13 \\
14 \\
15 \\
16\end{array}$ & $\begin{array}{l}\text { Glucose } \\
\text { Mannose } \\
\text { Raffinose } \\
\text { Trehalose } \\
\text { Fructose }\end{array}$ & $\begin{array}{l}\text { Utilisation of } \\
\text { monosaccharide }\end{array}$ \\
\hline $\begin{array}{l}17 \\
18 \\
19 \\
20\end{array}$ & $\begin{array}{l}\text { Urea } \\
\text { Indole } \\
\text { Nitrate } \\
\text { PAL }\end{array}$ & $\begin{array}{l}\text { Urease } \\
\text { Indole production } \\
\text { Nitrate reduction } \\
\text { Alkaline phosphatase }\end{array}$ \\
\hline $\begin{array}{l}21 \\
22 \\
23 \\
24 \\
25 \\
26 \\
27 \\
28 \\
29 \\
30 \\
31 \\
32 \\
33\end{array}$ & $\begin{array}{l}\text { ARG } \\
\text { PRO } \\
\text { HIS } \\
\text { LEU-GLY } \\
\text { PHE } \\
\text { GLU-GLU } \\
\text { LEU } \\
\text { PYRA } \\
\text { TYR } \\
\text { LANA } \\
\text { GLY } \\
\text { SER } \\
\text { CAT }\end{array}$ & Hydrolysis of aminopeptide \\
\hline
\end{tabular}

Reactions 3-11 test for the hydrolysis of a glycoside ester to release a coloured $p$-nitrophenol derivative.

Reactions 21-32 test for the hydrolysis of an aminopeptide linkage to release an orange 2-naphthylamine derivative. In reaction 20 , an $o$-phosphate linkage is hydrolysed.

(table II). Tests 1-17 are spontaneous colour reactions. Indole production (test 18 ) requires the addition of James's reagent (James et al., 1986) and nitrate production (test 19) the addition of sulphanilic acid and dimethyl- $\alpha$ naphthylamine. Tests nos. 20-32, for alkaline phosphatase and aminopeptidase production, require the addition of lauryl sulphate and Fast Blue BB. Catalase production (test 33 ) is detected by the addition of $\mathrm{H}_{2} \mathrm{O}_{2} \%$ to cupule 7 (aARA). Reactions were graded as strongly positive, weakly positive, very weakly positive or negative according to a supplied colour chart, and a pre-formed enzyme profile generated for each isolate. Organisms were grouped according to their identification by the methods of Sutter et al. (1986), and the pre-formed enzyme pattern characteristic of the species deduced. 
Table III. Comparison of efficacy of pre-formed enzyme systems

Number of isolates identified by

\begin{tabular}{|c|c|c|c|c|c|c|}
\hline \multirow[b]{3}{*}{ Organism } & \multirow{3}{*}{$\begin{array}{l}\text { Number of } \\
\text { strains tested }\end{array}$} & \multirow{2}{*}{\multicolumn{3}{|c|}{ RapID ANA }} & & \\
\hline & & & & & \multicolumn{2}{|c|}{ API prototype } \\
\hline & & Correct & Inadequate ID* & Incorrect & Correct & Incorrect \\
\hline Ps. anaerobius & 8 & 6 & 2 & 0 & 8 & 0 \\
\hline Ps. asaccharolyticus & 19 & 19 & 0 & 0 & 19 & 0 \\
\hline Ps. indolicus $\dagger$ & 1 & 1 & 0 & 0 & 1 & 0 \\
\hline Ps. magnus & 23 & 14 & 3 & 6 & 23 & 0 \\
\hline Ps. micros & 5 & 5 & 0 & 0 & 5 & 0 \\
\hline Indole-negative butyrate-producing cocci & 13 & \multicolumn{4}{|c|}{ Could not be confidently speciated } & \\
\hline Total & 69 & 45 & 5 & 6 & 56 & 0 \\
\hline
\end{tabular}

* When the RapID ANA profile could not differentiate between species, identification was described as 'inadequate ID'.

+ The single isolate of Ps. indolicus could not be differentiated satisfactorily from Ps. asaccharolyticus by standard identification techniques.

\section{Results}

The results from both pre-formed enzyme systems agreed well with identification based on standard identification techniques (table III), for all species groups except the indole-negative butyrate-producing cocci-Ps. prevotii and Ps. tetradius by Ezaki's classification (Ezaki et al., 1983). One indolepositive coccus could not be identified fully by standard methods, but was identified as Ps. indolicus by both enzyme systems.

The RapID ANA system was easy to use and could be inoculated rapidly; it required only two additional reagents. The minimum inoculum $(1 \mathrm{ml}$ of a McFarland standard 3 suspension) could be harvested from one plate after incubation for $48 \mathrm{~h}$ with even slow-growing GPAC. However, some reactions which were critical for correct identification were difficult to interpret.

Ps. asaccharolyticus and Ps. micros were easily identified and the profile numbers within each species were very similar. Ps. magnus often produced a borderline prolyl- $\beta$-naphthylamide reaction (PRO, cupule 3); if the reaction was read as positive, the organism was incorrectly identified as Ps. micros (table IV). Two reactions were responsible for producing an unsatisfactory level of identification (described as "inadequate ID" in the Rapid ANA Code Compendium): the glycyl- $\beta$ naphthylamide reaction (GLY, cupule 2) with two strains of Ps. anaerobius, and the arginine dihydrolase reaction $(\mathrm{ADH}$, cupule 9$)$ with two strains of Ps. magnus.

The indole-negative butyrate-producing cocci produced a large number of different patterns with both Rapid ANA and the prototype API system. This group of organisms is probably heterogeneous (Ezaki et al., 1983).

The prototype API system was slower to inoculate and required the addition of six different reagents. It was frequently difficult to harvest an adequate inoculum ( $5 \mathrm{ml}$ of a McFarland standard 4 suspension) from one plate after incubation for $48 \mathrm{~h}$, especially with Ps. micros. The aminopeptidase reactions (cupules 20-32) were sometimes difficult to interpret, but the critical reactions were almost always unequivocal. As this system is still at the prototype stage, a profile index has not yet been generated. Nevertheless, identification was remarkably easy - strains within each species produced very similar patterns, easily separable from strains of other species (table V). In particular,

Table IV. Organisms misidentified by the RapID ANA system

\begin{tabular}{|c|c|c|c|}
\hline Organism & $\begin{array}{l}\text { Number of } \\
\text { isolates }\end{array}$ & $\begin{array}{l}\text { Misleading } \\
\text { test }\end{array}$ & RapID ANA results \\
\hline Ps. anaerobius & 2 & GLY & $\begin{array}{l}90 \% \text { probability of } \\
\text { Ps. tetradius } \\
8 \% \text { probability of } \\
\text { Ps. anaerobius }\end{array}$ \\
\hline Ps. magnus & 2 & $\mathrm{ADH}$ & $\begin{array}{l}82 \% \text { probability of } \\
\text { Ps. tetradius } \\
18 \% \text { probability of } \\
\text { Ps. magnus }\end{array}$ \\
\hline & 5 & $\begin{array}{l}\text { PRO } \\
\text { ADH PRO }\end{array}$ & $\begin{array}{l}\text { Ps. micros } \\
\text { Ps. tetradius }\end{array}$ \\
\hline
\end{tabular}


Table V. Enzyme patterns with prototype API system

\begin{tabular}{|c|c|c|c|c|c|c|c|c|c|c|c|c|c|c|c|c|c|c|c|c|c|}
\hline \multirow[b]{2}{*}{ Organism } & \multirow{2}{*}{$\begin{array}{l}\text { Number } \\
\text { of } \\
\text { isolates }\end{array}$} & \multicolumn{20}{|c|}{ Characteristic reaction in cupule no. } \\
\hline & & 1 & 5 & 12 & 13 & 16 & 18 & 20 & 21 & 22 & 23 & 24 & 25 & 26 & 27 & 28 & 29 & 30 & 31 & 32 & 33 \\
\hline Ps. anaerobius & 8 & - & + & $\pm /+$ & $\mathrm{v}$ & $\pm 1+$ & - & - & - & + & - & - & - & - & $\overrightarrow{-}$ & - & - & - & - & - & - \\
\hline Ps. asaccharolyticus & 17 & - & - & - & - & - & + & - & + & - & $\pm /+$ & $-/ \mp$ & - & - & $\pm /+$ & - & $\pm /+$ & $\bar{z}$ & $\mathbf{v}$ & - & - \\
\hline Ps. indolicus & 2 & $\mathbf{v}$ & - & - & - & - & + & + & + & - & + & $\mathrm{v}$ & - & - & \pm & - & \pm & $\mp$ & + & - & - \\
\hline Ps. magnus & 23 & $\mathrm{v}$ & - & - & - & $v$ & - & $\mathrm{v}$ & + & - & $\mp / \pm$ & $\mathrm{v}$ & - & - & + & + & $\mathrm{v}$ & $\mathrm{v}$ & $\pm /+$ & - & $\mathrm{v}$ \\
\hline $\begin{array}{l}\text { Ps. micros } \\
\text { Indole-producing } \\
\quad \text { saccharolytic }\end{array}$ & 5 & - & - & - & - & - & - & + & + & + & + & + & + & + & + & + & + & + & + & + & - \\
\hline $\begin{array}{l}\text { organisms } \\
\text { Indole-negative } \\
\text { butyrate- } \\
\text { producing } \\
\text { organisms* }\end{array}$ & 2 & - & - & + & + & + & + & - & - & - & - & - & - & - & - & - & - & - & - & - & - \\
\hline Pattern 1 & 4 & - & - & - & - & - & - & - & + & - & + & - & - & - & $\pm /+$ & $\bar{z}$ & $\mp$ & - & \pm & $\bar{z}$ & - \\
\hline Pattern 2 & 3 & + & - & $\mathrm{v}$ & $v$ & $\mathrm{v}$ & - & - & + & - & + & v & - & - & + & $\mp$ & $\mathrm{v}$ & $\mathbf{v}$ & $\mp$ & $\mp$ & $\mathrm{v}$ \\
\hline Pattern 3 & 2 & - & - & - & - & - & - & - & - & - & - & - & - & - & - & - & - & - & - & - & + \\
\hline
\end{tabular}

Several reactions were always negative and have not been included. Reactions are graded when $>90 \%$ of the organisms produced the same reaction.

+ Strongly positive result; \pm weakly positive; $\mp$ very weakly positive; - negative.

* Four organisms in this group did not fit into any pattern.

there was a clear distinction between Ps. magnus and Ps. micros - organisms which previously have been separated by the size of the coccus (Holdeman et al., 1977; Sutter et al., 1986). As with the RapID ANA system, the indole-negative butyrate-producing cocci produced various patterns. These patterns were distinct from those produced by the well defined species.

The reproducibility of the prototype API system was investigated by re-testing several organisms blind. The results were very similar (table VI), showing that in optimum conditions the system is highly reproducible. The RapID ANA system has already been shown to be reproducible (Murray et al., 1985).

The importance of the correct inoculum for the prototype API system was tested by comparing a McFarland standard 2 suspension with a McFarland standard 4 suspension (table VII). Most organisms were identified correctly when a lighter inoculum was used (table V), though some individual reactions were weaker and two organisms could not be definitely identified. The possibility of using a light inoculum would be especially useful for PS. micros, a species which produced very strong reactions with even a weak inoculum.

Table VI. Reproducibility of prototype API system

\begin{tabular}{|c|c|c|c|c|c|}
\hline \multirow[b]{2}{*}{ Organism } & \multirow[b]{2}{*}{$\begin{array}{l}\text { Number } \\
\text { of strains } \\
\text { tested }\end{array}$} & \multirow[b]{2}{*}{$\begin{array}{l}\text { Number } \\
\text { of positive } \\
\text { reactions }\end{array}$} & \multicolumn{3}{|c|}{$\begin{array}{c}\text { Number of repeat reactions that } \\
\text { were }\end{array}$} \\
\hline & & & correct & $\begin{array}{l}\text { nearly* } \\
\text { correct }\end{array}$ & incorrect \\
\hline Ps. asaccharolyticus & 5 & 38 & 26 & 11 & 1 \\
\hline Ps. indolicus & 1 & 9 & 6 & 3 & 0 \\
\hline $\begin{array}{l}\text { Ps. magnus } \\
\text { Indole-negative butyrate-producing }\end{array}$ & 3 & 35 & 27 & 8 & 0 \\
\hline cocci & 5 & 32 & 20 & 11 & 1 \\
\hline
\end{tabular}

\footnotetext{
* Repeat reactions were classed as 'nearly correct' when they were one grade out (for instance, negative/very weakly positive), and 'incorrect' when they were two or more grades out.
} 
Table VII. Comparison of inoculum strength for prototype API system

\begin{tabular}{|c|c|c|c|}
\hline \multirow[b]{2}{*}{ Organism } & \multirow{2}{*}{$\begin{array}{l}\text { Number } \\
\text { of strains } \\
\text { tested }\end{array}$} & \multicolumn{2}{|c|}{$\begin{array}{c}\text { Number of strains correctly } \\
\text { identified with }\end{array}$} \\
\hline & & McFarland 2 & McFarland 4 \\
\hline Ps. anaerobius & 3 & 2 & 3 \\
\hline Ps. asaccharolyticus & 1 & 0 & 1 \\
\hline Ps. indolicus & 1 & 1 & 1 \\
\hline Ps. magnus & 5 & 5 & 5 \\
\hline Ps. micros & 2 & 2 & 2 \\
\hline $\begin{array}{l}\text { Indole-negative } \\
\text { butyrate-producing } \\
\text { cocci }\end{array}$ & 1 & 1 & 1 \\
\hline
\end{tabular}

\section{Discussion}

Identification of GPAC in clinical laboratories is based primarily on the detection of fatty-acid end-products by GLC, with the detection of indole production and the estimation of the size of the coccus as secondary tests (Sutter et al., 1986). However, their taxonomy is still debated (Rogosa, 1974) and their clinical importance not fully appreciated (Gorbach, 1985). GPAC are often not identified as far as the species level in most clinical laboratories.

In this study, both systems based on the detection of pre-formed enzymes were highly effective at identifying $P$ s. anaerobius, $P$ s. asaccharolyticus and

\section{REFERENCES}

Bourgault A-M, Rosenblatt J E, Fitzgerald R H 1980 Peptococcus magnus: a significant human pathogen. Annals of Internal Medicine 93: 244-248.

Ezaki T, Yabuuchi E 1985 Oligopeptidase activity of Grampositive anaerobic cocci used for rapid identification. Journal of General and Applied Microbiology 31: 255-265.

Ezaki T, Yamamoto N, Ninomiya K, Suzuki S, Yabuuchi E 1983 Transfer of Peptococcus indolicus, Peptococcus asaccharolyticus, Peptococcus prevotii and Peptococcus magnus to the Genus Peptostreptococcus and Proposal of Peptostreptococcus tetradius sp. nov. International Journal of Systematic Bacteriology 33: 683-698.

Finegold S M 1977 Anaerobic bacteria in human disease. Academic Press, New York.

Gorbach S L 1985 Anaerobic Cocci. In : Mandell G L et al. (eds) The principles and practice of infectious diseases, 2nd edn. John Wiley, New York, pp 1373-1375.

Holdeman L V, Cato E P, Moore W E C 1977 Anaerobic laboratory manual, 4th edn. Anaerobe Laboratory, Virginia Polytechnic Institute and State University, Blacksburg, VA, USA.

Huss V A R, Festl H, Schleifer K H 1984 Nucleic acid hybridization studies and deoxyribonucleic acid base compositions of anaerobic Gram-positive cocci. International Journal of Systematic Bacteriology 34: 95-101.
Ps. micros. The RapID ANA system (but not the API prototype) frequently misidentified $P$ s. magnus as Ps. micros, but this error can be prevented by looking at the gram-stained film to check the size of the coccus. Neither kit requires specialised equipment, and each can be inoculated and read on the same day. We conclude that these kits make the identification of the well characterised species of GPAC considerably simpler for the clinical laboratory.

A significant proportion of clinical isolates of GPAC do not fit into described species; $13(15 \%)$ of the original 95 in our set could not be confidently identified. Four of these strains produced large quantities of isovaleric acid as their main fatty-acid end-product, and did not correspond with any of the well characterised species. The enzyme patterns of two indole-producing organisms showed saccharolytic but not proteolytic activity-but by the current taxonomy, they are identified as Ps. asaccharolyticus. It is likely that further species of GPAC remain to be described. Until the taxonomy of GPAC is more comprehensive, pre-formed enzyme systems will be able to characterise many clinical isolates, but not to identify them.

We are grateful to the staff of the Microbiology Department, St Bartholomew's Hospital, particularly Miss Leslie Theobald, for laboratory assistance; to Mrs Sandy Gale for typing the manuscript; and to Mr G. Tillotson, formerly of API Laboratories, for practical advice. The prototype API kits were generously donated by API Laboratories.

James A L, Yeoman P, Rasburn J W, Ng M 1986 Sensitive reagents for detection of indole production by bacteria. Zentralblatt für Bakteriologie, Mikrobiologie und Hygiene $[A]$ 262: 195-202.

Karachewski N O, Busch E L, Wells C L 1985 Comparison of PRAS II, RapID ANA and API 20A systems for identification of anaerobic bacteria. Journal of Clinical Microbiology 21: $122-126$.

Lambert M A, Armfield A Y 1979 Differentiation of Peptococcus and Peptostreptococcus by gas-liquid chromatography of cellular fatty acids and metabolic products. Journal of Clinical Microbiology 10: 464-476.

Murray P R, Weber C J, Niles A C 1985 Comparative evaluation of three identification systems for anaerobes. Journal of Clinical Microbiology 22: 52.

Rogosa M 1974 Genus I Peptococcus and Genus II Peptostreptococcus. In: Buchanan R E, Gibbons N E (eds) Bergey's Manual of Determinative Bacteriology, 8th edn. Williams and Wilkins, Baltimore, p 518

Sutter V L, Citron D M, Edelstein M A C, Finegold S M 1986 Wadsworth Anaerobic Bacteriology Manual, 4th edn, Los Angeles.

Weiss N 1981 Cell wall structure of anaerobic cocci. Revue de l'Institut Pasteur de Lyon 14 (1): 53.

Wren M W D, Baldwin A W F, Eldon C P, Sanderson P J 1977 The anaerobic culture of clinical specimens: a 14 month study. Journal of Medical Microbiology 10: 49 